\title{
Van salafistisch gedachtegoed alleen kun je niet leven: de financiële zelfredzaamheid van 131 uitreizigers nader bekeken
}

\author{
Melvin Soudijn
}

In dit artikel staat het financiële leven centraal van 131 Nederlandse burgers die naar Syrië vertrokken om zich in het kalifaat te vestigen of zich bij de terroristische groepering IS aan te sluiten. Voor de analyse is gebruik gemaakt van hun bancaire transacties, teruggerekend tot een jaar voor hun vertrek. Het gaat in totaal om meer dan 60.000 transacties. Er is gekeken naar inkomsten uit arbeid, vormen van sociale bijstand, studiebeurzen en overige inkomsten of uitgaven. Op basis van deze gegevens is een goed beeld op te bouwen van hun financiële zelfredzaamheid, oftewel de mate waarin iemand in staat is op eigen kracht in zijn levensonderhoud te voorzien. Uit de analyse blijkt dat slechts 5 procent financieel zelfredzaam is. Voor een deel is deze slechte score te verklaren doordat bijna de helft van de uitreizigers jonger is dan 23 jaar en/of studiefinanciering ontvangt. Hun inkomenspositie verschilt nauwelijks van gewone studenten. Voor oudere uitreizigers is het een ander verhaal. Van de personen die 23 jaar of ouder zijn en al minstens een jaar geen studiefinanciering hebben ontvangen, is slechts 9 procent financieel zelfredzaam. Wellicht kan de afhankelijkheidsrelatie van de overheid in het kader van terrorismepreventie ook gebruikt worden om een vorm van toezicht te houden.

\section{Inleiding}

Nadat de Arabische Lente in 2011 Syrië bereikt en protesten tegen het regime van president Bashar al-Assad hardhandig worden neergeslagen, raakt het land in een steeds complexere burgeroorlog verwikkeld. In deze chaos gedijen diverse jihadistische strijdgroepen, waarvan IS vermoedelijk de bekendste is. In 2014 roept Abu Bakr al-Bagdhadi, als leider van IS, zijn zogeheten kalifaat uit. In diverse boodschappen worden moslims opgeroepen zich bij hem aan te sluiten en de gewapende strijd aan te gaan. Wereldwijd geven duizenden mensen aan deze oproepen gehoor en vertrekken naar Syrië.

Ook in Nederland tonen honderden personen interesse om te vertrekken (AIVD, 2017). Hoewel niet iedereen de daad bij het woord voegt of het slechts bij een mislukte uitreispoging houdt, weten anderen het strijdgebied in Syrië en Irak daadwerkelijk te bereiken. Volgens cijfers van de Nationaal Coördinator Terrorismebestrijding en Veiligheid (NCTV) gaat het in maart 2018 om circa 300 personen (NCTV, 2018). Daaronder bevinden zich 40 tot 60 kinderen die in Nederland zijn geboren (NCTV \& AIVD, 2017; AIVD, 2018).

Waarom personen zich in het kalifaat willen vestigen of zich bij terroristische bewegingen zoals IS aansluiten, is echter niet altijd duidelijk of op voorhand te 
voorspellen. Onderzoek naar terrorisme in bredere zin heeft laten zien dat er op individueel niveau een grote variëteit optreedt, wisselend van bijvoorbeeld een zucht naar avontuur en het zich verbonden voelen met een bepaalde subgroep tot het aanlopen tegen de verkeerde vrienden (Crenshaw, 1987; Schuurman, 2018; Dawson \& Amrarasingam, 2017; Fritz \& Young, 2017). Omdat demografische kenmerken ook behoorlijk kunnen verschillen (jong-oud, man-vrouw, getrouwdongetrouwd, migrant-autochtoon), is het lastig - zo niet onmogelijk - om 'het' profiel van een terrorist te bepalen.

Toch is er één variabele waarop de huidige generatie uitreizigers dezelfde overeenkomst lijkt te hebben, namelijk een lage sociaaleconomische klasse. In wat oudere, algemene overzichtsstudies naar terrorisme wordt nog opgemerkt dat terroristen voor wat betreft sociale klasse en inkomen niet afwijken van de gewone bevolking, of soms zelfs beter af zijn (Russel \& Miller, 1977; Monahan, 2012; LaFree \& Ackerman, 2009). Deze uitkomsten zijn echter gebaseerd op onderzoek naar terrorisme waar ook verdachten van de Duitse RAF, Spaanse ETA, Italiaanse Rode Brigades en Ierse IRA zijn meegenomen. Met het uitbreken van de Syrische burgeroorlog ziet het beeld voor uitreizigers er in ieder geval anders uit. In diverse Europese studies naar uitreizigers wordt opgemerkt dat zij grotendeels uit de lagere sociale klassen komen en geen goede positie op de arbeidsmarkt hebben - als zij al werkzaam zijn (Bakker \& De Bont, 2016; Bergema \& Van San, 2017; Weenink, 2015; Van Leyenhorst \& Andreas, 2017; Normark \& Ranstorp, 2017; Verwimp, 2016; El-Said \& Barett, 2017).

Naar aanleiding van deze uitkomsten brengen meerdere onderzoekers relatieve deprivatie in verband met radicalisering, of noemen het althans als een bestanddeel in een complex web van factoren (Miller \& Chauhan, 2017; Feddes, 2017; Dawson \& Amarasingam, 2017; Yusoufzai \& Emmerling, 2017). Subjectieve gevoelens van ontevredenheid over de eigen, achtergestelde positie ten opzichte van de gewone bevolking zouden dan mede aanleiding tot uitreizen kunnen zijn. Sociaaleconomische achterstand is ook vertaald naar criminologische ideeën over strain (Agnew, 2010; Cottee, 2011; Ljujic e.a., 2017). Dat houdt in dat het afwijkende gedrag (zoals bijvoorbeeld het zich aansluiten bij IS) mede voortkomt als oplossing voor het onvermogen aansluiting te vinden bij de conventionele maatschappij. Een laag opleidingsniveau, werkloosheid en een daaruit voortvloeiend laag of onvoldoende inkomen zijn dan tekenen dat de aansluiting wordt gemist. Een causaal verband tussen relatieve deprivatie of gevoelens van strain en radicalisering is echter niet aangetoond. Onderzoekers waarschuwen er dan ook voor om een lage sociaaleconomische positie te zien als de spreekwoordelijke kanarie in de koolmijn die radicalisering heet (bijvoorbeeld Agnew, 2010; Ljujic e.a., 2017; Verwimp, 2016; Hegghammer, 2016; Schils \& Pauwels, 2014). Per slot van rekening radicaliseert slechts een zeer kleine minderheid die in achtergestelde posities verkeert.

In dit artikel wordt voorgesteld om op een andere, meer pragmatische manier naar sociaaleconomische achtergrond te kijken. Namelijk door iemands financiële zelfredzaamheid in kaart te brengen, oftewel de mate waarin iemand in zijn eigen onderhoud kan voorzien of een beroep op financiële overheidssteun doet. Het pragmatische aan het meten van financiële zelfredzaamheid is dat het objectief 
inzicht biedt in de mate waarin iemand al dan niet te maken heeft met financiële problemen. Als hierbij een afhankelijkheidsrelatie van de overheid naar voren komt, dan kan deze in het kader van terrorismepreventie wellicht ook worden gebruikt om maatwerkoplossingen te zoeken, of een vorm van toezicht te houden. De centrale onderzoeksvraag van dit artikel luidt daarom: in welke mate zijn uitreizigers financieel zelfredzaam?

Alvorens op de bevindingen in te gaan, wordt eerst een achtergrondschets van de financiële aanpak van terrorisme en uitreizen gegeven. Vervolgens wordt stilgestaan bij de zogeheten Zelfredzaamheid-Matrix. Dit is een instrument dat kan helpen de zelfredzaamheid van burgers op verschillende domeinen in kaart te brengen. Relevant voor dit artikel is het domein financiën. In de paragraaf 'Onderzoeksgegevens' wordt uitgelegd welke stappen zijn doorlopen om tot de gegevensverzameling te komen en hoe de onderzoeksgroep is samengesteld. Er worden bij de onderzoeksgegevens ook enkele kanttekeningen geplaatst. Vervolgens worden de bevindingen gepresenteerd, onderverdeeld in verschillende soorten inkomen en maandsaldi. De bevindingen leiden in de paragraaf 'Zelfredzaamheid' tot het antwoord op de centrale onderzoeksvraag. Het artikel wordt afgesloten met een beschouwende conclusie waarin enkele beleidsaanbevelingen worden gedaan.

\section{Achtergrond}

Overheden treffen verschillende maatregelen om radicalisering en uitreizen tegen te gaan. Te denken valt bijvoorbeeld aan het innemen van de paspoorten van mensen die zich bij de jihad willen aansluiten, het instellen van een meldplicht voor bepaalde personen of gebieds- en contactverboden.

Door de Financial Action Task Force (FATF) is ook gewezen op het belang van financiële alertheid en maatregelen om radicalisering en uitreizen tegen te gaan. De FATF is een onafhankelijke intergouvernementele organisatie die zich al sinds 1990 bezighoudt met de bestrijding van witwassen en terrorismefinanciering (FATF, 2002; 2003; 2013a; 2013b; 2014). De FATF heeft hierbij standaarden en aanbevelingen ontwikkeld die internationaal worden erkend (FATF, 2012). De FATF heeft ook een handleiding beschikbaar gesteld om de 'International Convention for the Suppression of the Financing of Terrorism' juridisch te implementeren (FATF, 2016). Dat juridisch kader zorgt er onder meer voor dat financiële instellingen en overheidsorganisaties in staat zijn om in lijn met internationale verdragen en de grondwet terroristische activiteiten te onderkennen, te verstoren en de betrokken (niet-)natuurlijke personen te vervolgen.

De FATF merkt echter ook op dat de financiële transacties die met uitreizen gemoeid zijn vaak niet opvallen (FATF, 2015). Dat komt omdat de bedragen relatief laag zijn. Een paar honderd euro is genoeg om een vliegticket aan te schaffen richting Syrisch strijdgebied, eventueel aangevuld met wat extra aankopen zoals kampeerartikelen en een internationaal telefoonabonnement. Uitreizigers worden in hun uitreis niet ondersteund door internationale terroristenorganisaties, maar hebben voldoende aan hun eigen middelen van bestaan (arbeidsloon of 
uitkering), eventueel aangevuld met 'petty crime' (Oftedal, 2015; Basra e.a., 2016). Het is dan ook lastig gebleken een specifiek financieel profiel samen te stellen waarmee meldplichtige instellingen proactief jihadisten kunnen detecteren (AUSTRAC, 2015), temeer daar jihadistische websites adviseren hoe iemand zich financieel moet gedragen om bij de uitreis niet op te vallen (Keatinge, 2015).

Wat rest zijn dan financiële maatregelen achteraf. In het 'Actieprogramma Integrale Aanpak Jihadisme' van de NCTV (2014) zijn enkele van deze maatregelen terug te lezen. Zo moeten banktegoeden worden bevroren en uitkeringen, toeslagen of studiefinanciering worden stopgezet wanneer eenmaal bekend is dat iemand naar Syrië is vertrokken (maatregel 8 en 9). Door het afsnijden van deze inkomstenbronnen wordt gepoogd het levensonderhoud voor uitreizigers in Syrië te bemoeilijken. De NCTV ijvert er ook voor dat uitreizigers financieel in beeld worden gebracht door Financial Intelligence Unit (FIU)-Nederland of betrokken opsporingsteams. Dit heeft ten doel om de financiële relaties van de uitreizigers na te gaan op eventueel strafrechtelijk bewijs voor terrorismefinanciering (maatregel 33).

De rapportages en aanbevelingen van de FATF, evenals de maatregelen van de NCTV, zijn voornamelijk gericht op de bestrijding van terrorisme(financiering). In deze context dienen financiële gegevens om toegang tot rekeningen te bevriezen, geldstromen te stoppen, rechtszaken te onderbouwen of nieuwe verdachten te identificeren. Maar door deze focus op directe bestrijding komt minder aan bod dat financiële gegevens ook andersoortig inzicht kunnen bieden. Financiële gegevens vertegenwoordigen per slot van rekening een enorme rijkdom aan gegevens. Marketeers maken al jaren gebruik van de transactiegegevens of aankoophistorie van klanten om deze beter in beeld te brengen. Hetzelfde principe is ook op uitreizigers toepasbaar. Door het analyseren van financiële transacties kan de persoon achter de uitreiziger beter worden gekend. Inkomsten en uitgaven, of het verloop hiervan over een langere periode, geven inzicht in hun leven en gedrag. Dat hoeft niet direct tot opsporingsindicaties te leiden, maar zegt bijvoorbeeld iets over de sociaaleconomische positie van uitreizigers. Voor dit artikel wordt zelfs een stap verder gekeken, en wordt de financiële zelfredzaamheid van uitreizigers becijferd.

\section{Zelfredzaamheid-Matrix}

Voor het bepalen van de financiële zelfredzaamheid van uitreizigers wordt de 'Zelfredzaamheid-Matrix' (ZRM) gebruikt. De ZRM is een instrument ontwikkeld door de Gemeentelijke Gezondheidsdienst (GGD) Amsterdam en Rotterdam om de zelfredzaamheid van burgers in kaart te brengen. Met het instrument kunnen hulpverleners snel inzichtelijk maken op welke domeinen hun cliënten eventueel specifieke aandacht behoeven. Te denken valt aan domeinen als werk, opleiding, huisvesting, geestelijke gezondheid, sociale relaties of justitie. De matrix kent ook een specifiek aandachtsveld voor de financiële situatie. In de meest recente ZRM (Lauriks e.a., 2017) is financieel onderverdeeld in vijf classificaties, te weten:

1 Acute problematiek. Geen inkomsten. Groeiende, complexe schulden. 
2 Niet zelfredzaam. Te weinig inkomsten om te voorzien in basisbehoeften of spontaan/ongepast uitgeven. Groeiende schulden.

3 Beperkt zelfredzaam. Inkomsten uit uitkering om te voorzien in basisbehoeften. Gepast uitgeven. Eventuele schulden zijn ten minste stabiel of inkomen/ schuld wordt beheerd door derden.

4 Voldoende zelfredzaam. Inkomsten uit werk/(basis)pensioen/vrijwillige inkomensvoorziening (aanvullend pensioen) om te voorzien in basisbehoeften. Eventuele schulden zijn in eigen beheer. Eventuele schulden verminderen.

5 Volledig zelfredzaam. Uitsluitend inkomsten uit werk/(basis)pensioen/vrijwillige inkomensvoorziening. Aan het eind van de maand is geld over. Geen schulden.

Inkomsten worden in de ZRM onderverdeeld in twee soorten bronnen. De eerste bron betreft inkomsten uit gemeentelijke, regionale of nationale basisvoorzieningen waarmee armoede wordt voorkomen. Te denken valt aan de bijstandsuitkering voor volwassenen, een aanvullende studiebeurs, huur-, zorg- en kindertoeslagen. De tweede bron betreft inkomsten uit arbeid, activiteiten of diensten. Het gaat hier niet alleen om loon, maar ook om basispensioen, spaarproducten en inkomen uit eigen vermogen.

Zelfredzaamheid draait overigens niet alleen om kale cijfers. In de ZRM-handleiding wordt opgemerkt dat een persoon ook uit eigen beweging de hulp van anderen kan vragen of organiseren op het moment dat een daling van het functioneringsniveau plaatsvindt die hij niet zelf kan oplossen (Lauriks e.a., 2017). Van der Schors e.a. (2016) geven aan dat de hoogte van het inkomen niet direct van invloed is op het ontstaan van geldproblemen. Hoe mensen in het leven staan en hoe ze met hun geld omgaan wel.

\section{Onderzoeksgegevens}

Voor dit artikel is gebruik gemaakt van een dataset met financiële transacties van 131 uitreizigers. Om te komen tot deze dataset zijn de volgende vier stappen doorlopen.

De eerste stap begint met het vragen van toestemming voor een strategische analyse op het gebied van financiële bankgegevens van uitreizigers. Deze toestemming werd vanuit de dienstleiding bij de Dienst Landelijke Informatieorganisatie, de Landelijke Eenheid en het Landelijk Parket gegeven onder voorwaarde dat personalia en bedrijfsgegevens niet worden genoemd, de privacy wordt gewaarborgd en geen lopende opsporingsonderzoeken worden doorkruist. Ter controle van deze voorwaarden moest het artikel eerst aan de voornoemde dienstleidingen worden voorgelegd.

De tweede stap betreft het opvragen van een lijst uitreizigers. Op verzoek van de afdeling Financieel-economische criminaliteit bij de Landelijke Eenheid heeft het Landelijk Parket eind 2016 een selectie aangeleverd van 167 personen die op dat moment een zogeheten 'uitreizigersindicatie' hebben. Dit zijn personen van wie de politie sterke aanwijzingen heeft dat zij daadwerkelijk in het strijdgebied in 
Syrië verblijven of hebben verbleven. ${ }^{1}$ Personen die alleen bij de Algemene Inlichtingen- en Veiligheidsdienst (AIVD) bekend zijn, vallen hierbuiten.

De derde stap omvat het apart in beeld brengen van de financiën voor deze groep uitreizigers. Daartoe is eerst via het Landelijk Parket een overzicht van alle betaalen spaarrekeningen van de 167 uitreizigers bij de Nederlandse grootbanken opgevraagd. Vervolgens zijn van de geïdentificeerde betaal- en spaarrekeningen, wederom via het Landelijk Parket, de bijbehorende banktransacties opgevraagd. De tijdsperiode van de opgevraagde banktransacties beslaat een jaar, teruggerekend vanaf het moment van uitreis tot het moment dat de banktransacties zijn aangevraagd (1 juli 2017). Dus wanneer iemand op 6 mei 2014 is vertrokken, zijn de transactiegegevens opgevraagd vanaf 6 mei 2013 tot en met 1 juli 2017. Doorgaans bleek de rekening echter kort na de uitreis te zijn geblokkeerd of opgeheven.

Als vierde en laatste stap is gecorrigeerd voor inactieve rekeningen en minderjarigen. Bij enkele uitreizigers ontbreken namelijk bankgegevens of bleek de bankrekening over de opgevraagde periode inactief te zijn. Daarnaast zijn enkele personen nog minderjarig op de datum van vertrek. Minderjarigen zijn bij voorbaat niet zelfredzaam en vanuit financieel oogpunt niet interessant door een gebrek aan inkomsten. Door te corrigeren voor inactieve rekeningen en minderjarigen blijven uiteindelijk 131 van de 167 uitreizigers over. Het gaat om 97 mannen (74 procent) en 34 vrouwen (26 procent). De mannen zijn gemiddeld 24,9 jaar oud, met een leeftijd tussen de 18 en 42 jaar. De vrouwen zijn gemiddeld 24,6 jaar oud, met een leeftijd tussen de 18 en 45 jaar. Het merendeel van de uitreizigers is in Nederland geboren ( $\mathrm{N}=92)$. De een-na-grootste groep is geboren in Marokko $(\mathrm{N}=11)$, gevolgd door Irak $(\mathrm{N}=6)$ en Somalië $(\mathrm{N}=4)$. De overige achttien uitreizigers komen uit elf andere landen. Als naar de ouders van de uitreizigers wordt gekeken, heeft meer dan de helft van de uitreizigers een Marokkaanse achtergrond ( $\mathrm{N}=75) .13$ procent van de uitreizigers betreft een bekeerling ( $\mathrm{N}=17)$. Onder deze bekeerlingen bevinden zich twaalf autochtone Nederlandse personen. De 131 uitreizigers hebben in totaal 212 betaal- en spaarrekeningen in gebruik. Doorgaans hebben zij de beschikking over een of twee rekeningen. De uitzondering is één persoon met acht rekeningen. Voor de financiële analyse zijn alle 212 rekeningen in één Excel-bestand samengevoegd. In totaal beslaat het bestand 60.548 regels, waarbij iedere regel voor één financiële transactie staat. Zo'n transactie kan een eenmalige girale betaling aan een andere persoon, bedrijf of instantie zijn, een automatische afschrijving, een opname uit een geldautomaat of een bedrag dat op de rekening wordt ontvangen (giraal) of gestort (chartaal). Per transactie staan de rekeningnummers van de betrokken partijen, de datum (en afhankelijk van de bank, soms ook het exacte tijdstip), de tenaamstelling en natuurlijk het bedrag vermeld. Girale betalingen hebben vaak ook een korte

1 Een indicatie hoeft geen sluitend juridisch bewijs in te houden. Een vermoeden of aanwijzing is voldoende en wordt ter beoordeling overgelaten aan de desbetreffende regionale politie-eenheid, die de informatie muteert in de Basisvoorziening Handhaving (BVH) ex art. 8 Wet politiegegevens (Wpg). 
omschrijving die de transactie nader duidt. Als een gemeente bijvoorbeeld geld overmaakt, dan staat er ook bij in het kader waarvan.

Niet alle transactieregels zijn echter volledig gevuld. Soms ontbreekt de tenaamstelling van de tegenpartij. Waar mogelijk is deze handmatig toegevoegd als deze afgeleid kan worden uit het rekeningnummer of de omschrijving. Ook zijn er per bank soms verschillen in registreren. De ene bank gebruikt voor een bepaalde instantie bijvoorbeeld een afkorting, terwijl de andere bank de volledige naam van diezelfde instantie vermeldt. Als beide banken echter hetzelfde rekeningnummer hanteren, heeft de auteur de bedrijfsnamen gelijkgetrokken. Ook persoonsnamen zijn waar mogelijk gelijkgetrokken.

Uitreizigers hebben gemiddeld 451 transacties. Soms is een (secundaire) rekening inactief en beslaat slechts vijf regels met automatische afschrijvingen. Aan de andere kant van het spectrum bevindt zich een rekening met bijna 7.000 transacties. Dit betreft een persoon die van zijn persoonlijke rekening een 'goede doelen'stichting heeft gemaakt, waarop dagelijks tientallen kleine bedragen van donateurs worden ontvangen. Als deze rekening buiten beschouwing wordt gelaten, dan is het gemiddelde aantal transacties 399.

Omdat de periode waarin de rekeningen actief zijn onderling sterk kan verschillen (sommige worden direct na uitreis bevroren, andere niet), is gekozen voor vier identieke meetmomenten, namelijk elf maanden, zes maanden, drie maanden en één maand voor vertrek. De maand van vertrek zelf wordt niet meegenomen omdat hier grote onderlinge verschillen in zitten. Sommige personen vertrekken aan het begin van de maand, terwijl andere pas aan het eind van de maand vertrekken. Dit heeft vertekeningen in inkomsten tot gevolg. Om deze reden is ook elf maanden voor vertrek, in plaats van exact één jaar (twaalf maanden), als meetmoment vastgesteld.

Tot slot zijn de bevindingen aan vier deskundigen voorgelegd, te weten een unithoofd van de Dienst Sociale Zaken die ervaring met de ZRM heeft en drie politiefunctionarissen die op het gebied van contraterrorisme(financiering) actief zijn.

\section{Kanttekeningen}

De onderzoeksgegevens kunnen met recht uniek genoemd worden. De auteur is geen studie bekend waarbij gebruik is gemaakt van de bancaire transactiegegevens van een grote onderzoeksgroep over een ruime periode. De onderzoeksgegevens leveren dan ook gedetailleerd financieel inzicht op die voorheen bij uitreizigers ontbrak. Het laat niet alleen precies zien wat er legaal binnenkomt op de rekeningen, maar ook de herkomst. De rekeningafschriften geven verder informatie over de hoogte en bestemming van de uitgaven. Daarbij zijn inkomsten en uitgaven met elkaar te vergelijken om de bestedingsruimte te bepalen. Maar er zijn ook enkele kanttekeningen bij de onderzoeksgegevens te maken. Deze worden hierna besproken.

Een eerste kanttekening betreft de repliceerbaarheid en de controleerbaarheid van de bevindingen. Zoals Schuurman (2018) aangeeft, is het onderzoek naar terrorisme gebaat bij meer en creatief gebruik van primaire bronnen. Het nadeel van het gebruik van primaire bronnen, zoals bankgegevens van uitreizigers of andere doelgroepen, is dat deze bronnen niet algemeen toegankelijk zijn. Daar- 
voor zijn formele toestemming en screening nodig. Dat probleem geldt echter evenzogoed voor elk ander dossieronderzoek naar bijvoorbeeld georganiseerde misdaad. Desondanks wordt zulk onderzoek in Nederland regelmatig uitgevoerd (zie bijvoorbeeld Klerks, 2000; Kleemans e.a., 2002; Spapens, 2006; Van de Bunt, 2008; Kruisbergen, 2017).

Een tweede kanttekening is dat zwart of crimineel inkomen niet wordt gezien. Wellicht hebben sommige uitreizigers door bijvoorbeeld illegale arbeid of drugshandel meer geld tot hun beschikking dan uit de bankgegevens blijkt. In recente studies wordt dan ook gerefereerd aan de zogeheten 'crime-terror nexus' en wordt vermeld dat een deel van de uitreizigers een strafblad heeft (zie ook Basra e.a., 2016; Gallagher, 2016). Tegelijkertijd moet zwart of crimineel inkomen voor uitreizigers ook weer niet worden overschat. Volgens gesprekken met politiefunctionarissen aan wie de bevindingen zijn voorgehouden, betreft de geregistreerde criminaliteit van de 131 uitreizigers eerder vormen van agressie in het huiselijke of publieke domein dan bijvoorbeeld grootschalige drugshandel. Als er al sprake is van criminaliteit om financieel gewin, wordt het niveau van 'petty crime' niet ontstegen.

Een derde kanttekening is de vraag of wel alle bankrekeningen in beeld zijn gekomen. Mogelijk worden rekeningen aangehouden bij kleinere of buitenlandse banken die niet zijn aangeschreven in de derde stap van de datacollectie. Dat is goed mogelijk. Maar daarom zijn de uitreizigers van wie bankgegevens ontbraken, misschien juist omdat zij buiten de grootbanken bankierden, uit de studie gehaald. Bovendien bleek uit de analyse van de 131 uitreizigers die wel werden meegenomen, dat zij nauwelijks geldtransacties buiten de grootbanken om hadden. Eventuele negatieve saldi werden niet door onbekende bankrekeningen aangevuld, net zomin dat spaartegoeden naar onbekende of buitenlandse bankrekeningen verdwenen. Ter extra controle zijn de uitreizigers FIU-Nederland voorgehouden, maar ook daar zijn geen onverklaarbare geldstromen boven water gekomen.

Een vierde kanttekening betreft de vraag wat er met contant opgenomen geld gebeurt. Hiervan is niet duidelijk waar het aan wordt uitgegeven. Op zich maakt het voor deze analyse echter niet uit waar geld precies aan wordt uitgegeven. De focus van deze studie ligt op de mate van financiële zelfredzaamheid. Het gaat daarbij om de herkomst van het geld en in hoeverre uitgaven en inkomsten met elkaar in balans staan.

Een laatste kanttekening betreft het ontbreken van een controlegroep om het financiële gedrag tegen af te zetten. Het is onduidelijk in hoeverre het beeld dat uitreizigers laten zien significant afwijkt van hun peer group. Het opvragen van bankgegevens van onverdachte personen is om juridische redenen echter niet mogelijk gebleken. Ook de publiek toegankelijke inkomensgegevens van het Centraal Bureau voor de Statistiek (CBS) bieden weinig uitkomst omdat zij te breed van opzet zijn.

Ondanks deze kanttekeningen heeft het gebruik van bankgegevens meer voordan nadelen. Bankgegevens bieden op gedetailleerd niveau inzicht in de financiën van uitreizigers dat tot nog toe niet voorhanden was. 


\section{Bevindingen}

Om de financiële zelfredzaamheid van de uitreizigers te bepalen is naar vier soorten gegevens gekeken. De eerste soort gaat over inkomsten uit eigen werkzaamheden, activiteiten of diensten. De tweede soort betreft diverse vormen van overheidssteun, exclusief studiefinanciering. Studiefinanciering wordt apart als derde soort behandeld. Als laatste is gekeken naar de rekeningsaldi per maand. Elke categorie is in leeftijdsgroepen opgedeeld. Voorts wordt in de tekst apart gekeken naar verschillen tussen mannen en vrouwen, bekeerlingen en niet-bekeerlingen.

\section{Inkomsten uit arbeid, activiteiten of diensten}

Als eerste is gekeken naar het inkomen dat zelf is verdiend. Of beter gezegd, in navolging van de ZRM is gekeken naar inkomsten uit arbeid, activiteiten of diensten. Hieruit blijkt het volgende.

In de vier verschillende maanden die voor vertrek zijn gemeten, heeft 52 procent van de uitreizigers (68 van de 131 personen) op enig moment inkomsten uit eigen werkzaamheden. Tabel 1 geeft een geaggregeerd overzicht van de nettomaandinkomsten in de vier meetmomenten naar leeftijdscategorie.

Lang niet iedereen die werkt ontvangt gedurende elk van de vier meetmomenten salaris. In de leeftijdscategorie tot en met 22 jaar gaat het om 22 procent, in de leeftijdscategorie tot en met 27 jaar om 17 procent, maar boven de 33 jaar niemand. Alleen in de leeftijdscategorie 28-32 jaar werkt de helft van het totaal aantal werkenden het hele jaar door. Naarmate de uitreis nadert, daalt het aantal personen met inkomsten uit werk. Het gaat om een afname van bijna 50 procent of meer. Het is op basis van alleen de transactiegegevens niet duidelijk wat de uitval uit het arbeidsproces veroorzaakt. Volgens een politiefunctionaris die de resultaten zijn voorgelegd, kregen in ieder geval drie personen problemen op het werk door hun toenemende radicalisering. Deze drie wilden alleen nog volledig islamitisch gekleed aan het werk, waarop hen uiteindelijk de wacht werd aangezegd. ${ }^{2}$

Met het afnemen van het totaal aantal werkende personen is de mediaan één maand voor vertrek hoger dan elf maanden daarvoor (met uitzondering van de laatste leeftijdscategorie omdat er dan niemand meer werkt). De oorzaak van deze toename is dat het aantal uitreizigers met de relatief beter betaalde banen overblijft. De hoogste medianen zijn te vinden in de leeftijdscategorie 28-32 jaar. Dat is op zich niet verwonderlijk, omdat het hier om vaste dienstverbanden lijkt te gaan. In de jongere leeftijdscategorieën gaat het daarentegen vaak om uitzendwerk en kortstondige baantjes als vakkenvuller in de supermarkt, krantenbezorger of telefonische helpdeskmedewerker. Voor zowel de relatief hogere als de lagere inkomens lijkt doorgaans geen hoge opleiding vereist. De meesten zijn werkzaam als verkoper in een winkel, schoonmaker en helpdeskmedewerker,

2 Zie ook Van San (2017, 43). Zij tekent in veldinterviews op dat sommige jongeren uit eigen beweging zijn gestopt met werken omdat zij het niet langer met hun geloof in overeenstemming vonden. 
Tabel 1 Nettomaandinkomsten uit arbeid $(N=68)$

\begin{tabular}{|c|c|c|c|c|}
\hline Maanden & II & 6 & 3 & I \\
\hline \multicolumn{5}{|c|}{ Leeftijd I8-22 (N=36) } \\
\hline Aantal personen & 24 & 23 & 17 & 15 \\
\hline Totaalbedrag & 15.646 & 10.646 & 8.409 & 12.339 \\
\hline Mediaan & 432 & 219 & 353 & 535 \\
\hline Max. & 1.655 & 3.190 & 2.647 & 2.051 \\
\hline Min. & 60 & 12 & 12 & 12 \\
\hline \multicolumn{5}{|c|}{ Leeftijd 23-27 $(N=18)$} \\
\hline Aantal personen & 17 & 14 & 13 & 5 \\
\hline Totaalbedrag & $|2.69|$ & 13.945 & $|0.43|$ & 6.943 \\
\hline Mediaan & 812 & 738 & 662 & 1.670 \\
\hline Max. & 2.997 & 2.507 & 2.716 & 2.141 \\
\hline Min. & 18 & 84 & 229 & 105 \\
\hline \multicolumn{5}{|c|}{ Leeftijd 28-32 ( $N=9)$} \\
\hline Aantal personen & 8 & 6 & 6 & 4 \\
\hline Totaalbedrag & 9.288 & 8.220 & 10.395 & 6.834 \\
\hline Mediaan & 1.305 & 1.693 & 2.136 & 1.849 \\
\hline Max. & 1.806 & 1.951 & 2.335 & 2.500 \\
\hline Min. & 389 & 59 & 3 & 635 \\
\hline \multicolumn{5}{|c|}{ Leeftijd 33-45 (N=5) } \\
\hline Aantal personen & 4 & 2 & 1 & 0 \\
\hline Totaalbedrag & 3.484 & 4.624 & 723 & 0 \\
\hline Mediaan & 1.080 & 2.312 & 723 & 0 \\
\hline Max. & 1.305 & 2.624 & 723 & 0 \\
\hline Min. & 19 & 2.000 & 723 & 0 \\
\hline
\end{tabular}

maar er zijn ook een lasser en een onderhoudsmonteur. Een enkeling maakt deel uit van een re-integratieproject.

Onderling zijn grote verschillen in inkomen op te tekenen. In tabel 1 is bijvoorbeeld te zien dat een jongere een halfjaar voor vertrek 3.190 euro nettosalaris ontvangt, terwijl een andere jongere die maand slechts 12 euro binnenkrijgt. Dergelijke maxima en minima zijn echter geen reguliere inkomens maar eenmalige uitschieters. De maxima worden veroorzaakt doordat die maand toevallig vakantiegeld wordt uitgekeerd. In de maanden daarvoor of daarna komt weer veel minder binnen. De minima zijn werk naar stukloon, waarbij die maand slechts enkele uren is gewerkt of eenmalig reclamefolders zijn rondgebracht.

Afhankelijk van de arbeidssector ligt het Nederlandse minimumloon in de jaren 2012-2015 op ongeveer 1.300 euro netto per maand. ${ }^{3}$ Gemeten over drie van de

3 Zie https://loonwijzer.nl/home/nieuws/Salarisnieuws/loonstrook-2015-nettoloon-stijgt-voormiddeninkomens-2-12-2014. 
vier meetmomenten blijkt dat negen personen deze ondergrens weten te halen. In vijf gevallen kan daarbij zelfs van een modaal inkomen worden gesproken. ${ }^{4} \mathrm{Het}$ hoogst genoteerde gemiddelde nettomaandinkomen hierbij is 2.096 euro. Doorgaans verdienen jongeren niet zoveel, hooguit een paar honderd euro in de maand, maar er zijn ook uitzonderingen. Twee jongens van 22 jaar verdienen met uitzendwerk om de vier weken bijna 2.000 euro nettosalaris. Dat is een meer dan modaal inkomen.

Tot de tien best verdienende personen uit tabel 1 behoort slechts één vrouw. Zij bekleedt de laatste plaats en verdient ruim de helft minder dan de best verdienende mannelijke uitreiziger (een totaalinkomen van 8.383 versus 3.748 euro in de vier onderzochte maanden). Vrouwen nemen percentueel ook minder vaak aan het arbeidsproces deel dan mannen. Slechts 38 procent van alle vrouwen heeft op enig moment een arbeidsbetrekking ten opzichte van 56 procent van de mannen. Acht van de zeventien bekeerlingen verkrijgen op enig moment inkomen uit arbeid. Dit heeft echter niet veel om het lijf. Doorgaans betreft het slechts enkele tientjes tot een paar honderd euro per maand. De werkbetrekking is ook van korte duur. Geen enkele bekeerling heeft vaker dan twee meetmomenten officieel werk.

Tot slot, in tabel 1 zijn ook enkele onrechtmatige inkomsten geslopen. Zo verdient een bepaalde uitreiziger een halfjaar voor vertrek 2.000 euro netto met advieswerkzaamheden. Uit politieonderzoek blijkt echter dat het om inkomen uit fraude gaat. De persoon in kwestie rommelde met persoonsgebonden budgetten en had hiervoor schijnconstructies opgezet. Een ander geval betreft een uitreiziger die vermoedelijk een of meer personen onder zijn identiteit liet werken. Maanden nadat hij is vertrokken, blijkt er nog wekelijks via een (Belgisch) uitzendwerkbureau loon op zijn rekening binnen te komen. Niet alle inkomens zijn echter op rechtmatigheid door de politie onderzocht. Het is dan ook onduidelijk in welke mate tabel 1 is vervuild met frauduleus inkomen.

\section{Overheidssteun}

Als tweede bron van inkomsten is gekeken naar de stortingen van diverse uitkerende instanties. Het gaat hier om inkomsten uit gemeentelijke, regionale of nationale basisvoorzieningen in de vorm van diverse soorten bijstandsuitkeringen, schuldhulpverlening, huur-, zorg- en kindertoeslagen. Studiefinanciering is hierbuiten gehouden en wordt in de volgende paragraaf apart behandeld.

In de vier verschillende maanden die voor vertrek zijn gemeten, krijgt 95 procent van de uitreizigers (124 van de 131 personen) een vorm van overheidssteun. Deze steun wordt betrokken van verschillende instanties en verschilt qua hoogte. Tabel 2 geeft per leeftijdscategorie een overzicht van de overheidssteun die bij de uitreizigers in de vier gemeten maanden is binnengekomen.

Het aantal personen dat overheidssteun ontvangt, blijft per leeftijdscategorie redelijk stabiel, alhoewel het aantal iets toeneemt in de leeftijdscategorie 23-27

4 Volgens de website www.gemiddeld-inkomen.nl/inkomens-vanaf-1970/is 1.773 euro een modaal nettomaandinkomen in het jaar 2013, respectievelijk 1.826 euro in 2015. 
Tabel 2 Overheidssteun ${ }^{a}(N=124)$

\begin{tabular}{|c|c|c|c|c|}
\hline Maanden & II & 6 & 3 & I \\
\hline \multicolumn{5}{|c|}{ Leeftijd I8-22 (N=54) } \\
\hline Aantal personen & 46 & 48 & 48 & 48 \\
\hline Totaalbedrag & 10.244 & 6.258 & 6.499 & 10.354 \\
\hline Mediaan & 84 & 78 & 78 & 79 \\
\hline Max. & 3.405 & 1.509 & 1.353 & 2.894 \\
\hline Min. & 70 & 70 & 28 & 28 \\
\hline \multicolumn{5}{|c|}{ Leeftijd 23-27 ( $N=42)$} \\
\hline Aantal personen & 29 & 25 & 31 & 34 \\
\hline Totaalbedrag & 13.359 & 9.542 & 16.394 & 20.339 \\
\hline Mediaan & 89 & 178 & 286 & 230 \\
\hline Max. & 2.040 & 1.222 & 2.652 & 3.788 \\
\hline Min. & 69 & 40 & 40 & 40 \\
\hline \multicolumn{5}{|c|}{ Leeftijd 28-32 (N=I7) } \\
\hline Aantal personen & 15 & 13 & 15 & 15 \\
\hline Totaalbedrag & 15.234 & 11.220 & 15.538 & 14.823 \\
\hline Mediaan & 915 & 889 & 1.037 & 851 \\
\hline Max. & 2.843 & 2.394 & 2.053 & 4.579 \\
\hline Min. & 70 & 30 & 78 & 78 \\
\hline \multicolumn{5}{|c|}{ Leeftijd 33-45 $(N=I I)$} \\
\hline Aantal personen & 10 & 8 & 6 & 8 \\
\hline Totaalbedrag & 12.002 & 6.184 & 6.295 & 7.620 \\
\hline Mediaan & 1.228 & 809 & 1.099 & 918 \\
\hline Max. & 2.585 & 1.763 & 1.957 & 1.857 \\
\hline Min. & 89 & 72 & 103 & 102 \\
\hline
\end{tabular}

a Onder overheidssteun is ook teruggaaf 'inkomstenbelasting premie volksverzekering' (IB/PVV) opgenomen. Dit is een heffingskorting die kan worden ontvangen als een van de twee (fiscale) partners geen of een laag inkomen heeft. IB/PVV is 6 procent van de totale overheidssteun.

jaar. Deze stijging hangt deels samen met de daling van het aantal werkenden in dezelfde leeftijdscategorie (zie tabel 1).

In alle leeftijdscategorieën is het totaalbedrag aan overheidssteun zes maanden voor vertrek het laagst, zowel in absolute als in relatieve zin. Wat hiervan de oorzaak is, is onbekend. Deze dip heeft op de mediaan in de jongste leeftijdscategorie echter vrij weinig effect. De mediaan blijft hier gedurende de vier meetmomenten redelijk stabiel, omdat de meeste jongeren doorgaans alleen een klein bedrag aan huur- of zorgtoeslag ontvangen. Er zijn echter ook uitzonderingen, zoals iemand van 22 jaar die elf maanden voor vertrek 3.405 euro ontvangt. Dit bedrag valt zo hoog uit doordat onder andere een voorschot van enkele maanden kinderopvang door de overheid wordt overgemaakt. 
In de leeftijdscategorie van 23-27 jaar groeit de mediaan ieder meetmoment mee om uiteindelijk op 230 euro per maand uit te komen. Dat bedrag is echter nog altijd beduidend minder dan in de twee oudere leeftijdscategorieën, waar de mediaan elf maanden voor vertrek op 1.228 euro staat. De relatief hoge medianen zijn het gevolg van het simultaan aanspreken van zowel een werkloosheidsuitkering als huurtoeslagen, zorgtoeslagen en kindgebonden budgetten. Op deze manier ontvangen vier personen in drie van de vier maanden meer dan 1.700 euro steun per maand.

Als naar de tien personen met het hoogste totaalinkomen uit overheidssteun wordt gekeken (variërend van 8.419 tot 4.825 euro in de vier gemeten perioden), betreffen acht hiervan vrouwen met kinderen. Als groep doen vrouwen (97 procent) iets vaker een beroep op de overheid dan mannen (94 procent).

Ook vijftien van de zeventien bekeerlingen doen regelmatig een beroep op overheidssteun. In drie gevallen gaat het specifiek om een Wajong-uitkering. Dat is een uitkering die op jonge leeftijd wordt toegekend aan personen die wegens een langdurige (geestelijke) ziekte of handicap geen mogelijkheid tot werk hebben. De uitkering kan tot de AOW-leeftijd doorlopen. Zes bekeerlingen onder de 28 jaar ontvangen omgerekend 1.000 euro of meer per gemeten tijdsperiode, ruim boven de mediaan.

\section{Studiefinanciering}

Als derde punt van aandacht is apart gekeken naar studiefinanciering. De reden hiertoe is dat de groep uitreizigers relatief jong is, en er dus grote kans bestaat dat zij nog met een opleiding bezig zijn. In totaal blijkt dan ook dat 46 procent van de uitreizigers (60 van de 131 personen) een beroep doet op studiefinanciering via Dienst Uitvoering Onderwijs (DUO) gedurende een of meer meetmomenten. Tabel 3 geeft per leeftijdscategorie voor studiefinanciering het volgende overzicht.

Tabel 3 laat zien dat, gemeten over het jaar, het aantal mensen met een studiebeurs licht afneemt. Elf maanden voor vertrek betreft het 41 personen, om te dalen naar 34 personen één maand voor de uitreis. Tegelijkertijd stijgt gedurende het jaar het totaalbedrag dat aan studiefinanciering wordt toegekend en neemt de hoogte van de mediaan ook toe, uitgezonderd de oudste leeftijdscategorie.

Opvallend is dat in de jongste leeftijdscategorie één persoon een maand voor vertrek maar liefst 4.854 euro aan studiebeurs heeft ontvangen. Uit de transactieomschrijving is niet af te leiden wat hier de reden van is. Mogelijk betreft het een extra lening, maar dat wordt verder niet vermeld. De andere maanden ontving deze uitreiziger rond de 1.200 euro.

Over het algemeen gesproken zijn de bedragen die worden ontvangen redelijk stabiel. Bij tien personen keert DUO een maand voor vertrek 50 euro of meer uit vergeleken met de voorgaande periode. Twee andere personen ontvangen juist minder. De rest ontvangt min of meer hetzelfde als de voorgaande periode. Wel is er veel uitval. Zo ontvangen negen personen een halfjaar voor vertrek geen studiefinanciering meer. Drie maanden voor vertrek stijgt dit aantal naar zeventien per- 
Tabel 3 DUO $(N=60)$

\begin{tabular}{lllll}
\hline Maanden & I I & $\mathbf{6}$ & $\mathbf{3}$ & I \\
\hline Leeftijd I8-22 (N=44) & & & & \\
Aantal personen & 3 I & 3 I & 30 & 25 \\
Totaalbedrag & 13.795 & 17.53 I & 15.470 & 18.596 \\
Mediaan & 394 & 405 & 549 & 539 \\
Max. & 1.187 & 2.605 & 992 & 4.854 \\
Min. & 75 & 75 & 75 & 196 \\
Leeftijd 23-27 $(\mathrm{N}=$ /3) & & & & \\
Aantal personen & 7 & 7 & 8 & 7 \\
Totaalbedrag & 3.955 & 4.894 & 8.443 & 5.534 \\
Mediaan & 588 & 588 & 885 & 853 \\
Max. & 1.095 & 1.069 & 2.719 & 1.362 \\
Min. & 80 & 380 & 380 & 22 I \\
Leeftijd 28-45 $(\mathrm{N}=3)$ & & & & \\
Aantal personen & 3 & 2 & 2 & 2 \\
Totaalbedrag & 1.544 & 2.407 & 964 & 964 \\
Mediaan & 525 & 1.204 & 482 & 482 \\
Max. & 777 & 1.612 & 537 & 537 \\
Min. & 242 & 795 & 427 & 427 \\
\hline
\end{tabular}

sonen. Uiteindelijk ontvangen 26 personen één maand voor vertrek geen studiefinanciering meer. Dit is een uitval van 43 procent op het totaal aantal personen dat studiefinanciering ontvangt. ${ }^{5}$

Er is weinig verschil in bedragen tussen mannen en vrouwen op te maken. Wel ontvangt de groep vrouwen (38 procent) iets minder vaak studiefinanciering dan de groep mannen (48 procent).

Zes van de zeventien bekeerlingen ontvangen op enig moment studiefinanciering. Geen van hen ontvangt echter gedurende alle vier de meetmomenten studiefinanciering. Slechts twee personen hebben op drie van de vier meetmomenten vanuit DUO geld ontvangen.

Tot slot kan worden opgemerkt dat drie personen die studiefinanciering ontvangen, ouder zijn dan 28 jaar. Zij zijn respectievelijk 31, 32 en 42 jaar oud. Hier zit echter ook de persoon bij die eerder 2.000 euro door fraude ontving. Het is op basis van de financiële data niet na te gaan of deze persoon ook daadwerkelijk studeerde.

\section{Maandsaldi}

Het vierde en laatste punt van aandacht is het totaalverloop op de betaal- en spaarrekeningen en staat los van de hoogte van het inkomen. Belangrijk is nu de

5 De reden voor deze uitval is niet uit de financiële data af te leiden. Mogelijk zijn zij voortijdig gestopt, maar het kan ook zijn dat zij hun studie met succes hebben afgerond. 
Tabel $4 \quad$ Positieve maandsaldi $(N=118)$

\begin{tabular}{|c|c|c|c|c|}
\hline Maanden & II & 6 & 3 & $\mathbf{I}$ \\
\hline \multicolumn{5}{|c|}{ Leeftijd I8-22 (N=53) } \\
\hline Aantal personen & 21 & 33 & 27 & 23 \\
\hline Totaalbedrag & 6.523 & 31.384 & 6.980 & 8.737 \\
\hline Mediaan & 195 & 188 & 164 & 140 \\
\hline Max. & 1.291 & 21.919 & 1.093 & 2.044 \\
\hline Min. & 4 & 6 & 3 & 1 \\
\hline \multicolumn{5}{|c|}{ Leeftijd 23-27 (N=36) } \\
\hline Aantal personen & 16 & 16 & 16 & 20 \\
\hline Totaalbedrag & 2.226 & 4.334 & 6.384 & 7.326 \\
\hline Mediaan & 95 & 187 & 260 & 148 \\
\hline Max. & 515 & 1.120 & 1.326 & 1.733 \\
\hline Min. & 1 & 1 & 1 & 2 \\
\hline \multicolumn{5}{|c|}{ Leeftijd 28-32 (N=I7) } \\
\hline Aantal personen & 7 & 8 & 9 & 6 \\
\hline Totaalbedrag & 1.325 & 1.459 & 3.989 & 2.061 \\
\hline Mediaan & 73 & 122 & 456 & 278 \\
\hline Max. & 474 & 637 & 958 & 881 \\
\hline Min. & 46 & 13 & 39 & 67 \\
\hline \multicolumn{5}{|c|}{ Leeftijd 33-45 $(N=12)$} \\
\hline Aantal personen & 5 & 9 & 2 & 4 \\
\hline Totaalbedrag & 2.531 & 3.630 & 629 & 1.414 \\
\hline Mediaan & 237 & 80 & 315 & 94 \\
\hline Max. & 1.565 & 1.955 & 532 & 1.224 \\
\hline Min. & 5 & 9 & 98 & 2 \\
\hline
\end{tabular}

vraag of er aan het eind van de maand geld overblijft of dat er meer uit gaat dan inkomt. Tabel 4 geeft eerst een beeld van de positieve eindsaldi per meetmoment. Vervolgens geeft tabel 5 een beeld van de negatieve eindsaldi.

Uit tabel 4 blijkt dat 118 van de 131 uitreizigers minstens eenmaal de maand positief hebben afgesloten. Maar gemeten over alle vier de meetperioden lukt dit slechts drie personen. Bij nog eens vijftien andere personen komt er meer geld binnen dan eruit gaat in drie van de vier meetmomenten. De overige 100 personen staan twee of drie meetmomenten in het rood. Er is weinig verschil tussen de leeftijdscategorieën.

Als de maand positief wordt afgesloten, gaat het doorgaans om een paar honderd euro, alhoewel de mediaan per tijdsperiode kan schommelen. Bij de jongste leeftijdscategorie valt een halfjaar voor vertrek een flinke uitschieter op. In die maand eindigt een persoon met maar liefst 21.919 euro op zijn rekening. Uit de 
transactieomschrijvingen blijkt dat deze persoon in die maand een vergoeding van bijna 22.000 euro wegens letselschade krijgt uitgekeerd.

Naast inkomen uit arbeid, overheidssteun en studiefinanciering zijn er enkele andere terugkerende posten aan te merken die de rekeningen voeden. Zo hebben sommige personen een gezinshuishouding en wordt de rekening aangevuld met het inkomen van de partner. Soms ontvangen jongeren steun van hun ouders in de vorm van 50 tot een paar honderd euro per maand. Incidentele boekingen maken het plaatje compleet. Zo worden er spullen via Marktplaats verkocht, of verkoopt iemand zijn auto voor een paar duizend euro.

Er is bij geen van de uitreizigers financiering van overzeese salafistische stichtingen of organisaties aangetroffen. Wel ontvingen drie personen stelselmatig Nederlandse donaties met een religieus karakter. Elk geval is anders. Nummer één krijgt maandelijks exact 1.000 euro van een wettelijk erkende islamitische stichting uit Nederland. Nummer twee is zelf een dozijn niet-erkende 'goede doelen'-stichtingen begonnen. Hij vraagt hiertoe op islamitische fora geld in het kader van bijvoorbeeld een hulpactie voor Syrië, Afghanistan, weeskinderen, speelgoed, waterputten of zusters. Honderden bezoekers van deze fora geven aan zijn oproepen gehoor en doneren kleine bedragen van 1 of 2 euro, maar soms ook grote bedragen van een paar honderd euro. ${ }^{6}$ In totaal haalt hij gedurende de vier meetmomenten ruim 15.000 euro op. De derde persoon krijgt vanaf een halfjaar voor vertrek van meer dan 40 donateurs kleine bedragen onder vermelding van bijvoorbeeld 'de huur van een zuster in nood'. Vaak gaan deze overboekingen gepaard met religieuze teksten. Daarmee ontvangt zij ruim 1.000 euro in totaal. Bij sommige extra inkomstenbronnen kunnen vraagtekens worden gezet. Zo storten diverse uitreizigers zelf een paar honderd euro contant op hun rekening. Het is onbekend waar dit geld vandaan komt. Verder doen twee personen vermoedelijk aan illegale onderverhuur. Eén persoon maakt bijvoorbeeld iedere maand de huur over naar een woonstichting, maar krijgt in diezelfde periode van een particulier ook geld op zijn rekening gestort met de omschrijving 'huur'. Deze particulier betaalt 100 euro meer dan de uitreiziger aan de woonstichting kwijt is. Ook hebben twee personen vlak voor de uitreis een extra lening ontvangen of de kredietlimiet verhoogd. ${ }^{7}$ Zodra dit is toegekend, wordt het geld contant opgenomen om vervolgens uit te reizen.

Tabel 5 geeft het negatieve saldo per leeftijdscategorie in de vier meetmomenten weer. Negatieve saldi ontstaan als de uitgaven per meetmoment groter zijn dan de inkomsten. Het blijkt dat 121 uitreizigers minstens eenmaal de maand negatief hebben afgesloten. Aan het begin en eind van het jaar is het aantal uitreizigers met een negatief saldo min of meer gelijk. Acht personen staan op alle vier de meetmomenten in het rood. Nog eens 40 personen staan drie van de vier meetmomenten rood.

6 Soms doneren personen zelfs geld met het verzoek om voor een ziek familielid of een goed tentamen te bidden.

7 Het is onbekend hoeveel uitreizigers een aanvraag voor een lening of kredietverhoging hebben ingediend, maar zijn afgewezen. De meeste uitreizigers hebben een te zwakke financiële uitgangspositie om reguliere financiële instellingen voldoende zekerheden en waarborgen te bieden. 
Tabel $5 \quad$ Negatieve maandsaldi per tijdsperiode $(N=121)$

\begin{tabular}{|c|c|c|c|c|}
\hline Maanden & II & 6 & 3 & $\mathbf{I}$ \\
\hline \multicolumn{5}{|c|}{ Leeftijd I8-22 (N=53) } \\
\hline Aantal personen & 34 & 21 & 29 & 35 \\
\hline Totaalbedrag & -7.072 & -20.640 & -7.684 & -15.002 \\
\hline Mediaan & -111 & -191 & -218 & -149 \\
\hline Max. & -943 & -10.808 & -852 & -2.563 \\
\hline Min. & -1 & -8 & -3 & -2 \\
\hline \multicolumn{5}{|c|}{ Leeftijd 23-27 (N=39) } \\
\hline Aantal personen & 21 & 21 & 25 & 24 \\
\hline Totaalbedrag & -12.536 & $-5.58 \mathrm{I}$ & -15.795 & -6.831 \\
\hline Mediaan & -296 & -69 & -173 & -107 \\
\hline Max. & -4.930 & -1.012 & -8.967 & -1.332 \\
\hline Min. & -18 & -4 & -2 & -3 \\
\hline \multicolumn{5}{|c|}{ Leeftijd 28-32 (N=18) } \\
\hline Aantal personen & 12 & II & 9 & 12 \\
\hline Totaalbedrag & -3.053 & -5.772 & -1.523 & -3.377 \\
\hline Mediaan & -89 & -458 & -63 & -184 \\
\hline Max. & -927 & -2.189 & -225 & -848 \\
\hline Min. & -3 & -1 & -8 & -1 \\
\hline \multicolumn{5}{|c|}{ Leeftijd 33-45 $(N=I I)$} \\
\hline Aantal personen & 7 & 3 & 9 & 8 \\
\hline Totaalbedrag & -2.922 & -1.401 & -2.523 & -1.152 \\
\hline Mediaan & -293 & -615 & -148 & -55 \\
\hline Max. & -1.060 & -717 & -1.419 & -543 \\
\hline Min. & -66 & -69 & -3 & -3 \\
\hline
\end{tabular}

Bij drie van de vier leeftijdscategorieën neemt de mediaan een maand voor vertrek af vergeleken met de periode daarvoor. Het is onduidelijk wat hier de verklaring voor is. Mogelijk hebben sommige uitreizigers in de voorgaande perioden zoveel negatief saldo opgebouwd, dat zij maximaal rood staan en vlak voor vertrek minder uitgaven kunnen doen. Het is echter ook mogelijk dat een aantal uitreizigers vlak voor vertrek juist geen grote schulden wil hebben openstaan om niet aan de grens te worden tegengehouden.

Het hoogste negatieve saldo ( -10.808 euro) wordt zes maanden voor de uitreis in de jongste categorie gevonden. Het blijkt dat de desbetreffende persoon die maand 10.000 euro contant van zijn spaarrekening heeft opgenomen. Ook bij andere saldi die sterk negatief oplopen, blijkt vaak dat er een paar honderd tot meer dan 1.000 euro contant is opgenomen.

$\mathrm{Bij}$ zes personen worden posten aangetroffen die spreken over het aflossen van schulden bij de gemeente of achterstallige betalingen in relatie tot een woningstichting of energiemaatschappij. Het gaat hierbij doorgaans om minder dan 100 
euro per maand. Bij diverse andere uitreizigers zijn de schulden boven het hoofd gegroeid. Drie personen staan in de gemeten onderzoeksperiode volledig onder bewind. Hun vaste lasten zijn door een bewindvoerder overgenomen, waarbij zijzelf enkele tientjes leefgeld per week krijgen. Verder heeft 9 procent van de uitreizigers (twaalf van de 131 personen) regelingen met deurwaarders of incassobureaus getroffen. Buiten de vier meetmomenten hebben nog eens zeven uitreizigers een regeling met deurwaarders of incassobureaus. In totaal hebben 28 uitreizigers (21 procent) met schuldenproblematiek te maken (gehad). Bijna de helft van de bekeerlingen (47 procent) is met schuldenproblematiek geconfronteerd tegen 'slechts' 18 procent van de niet-bekeerlingen. Eenzelfde soort vergelijking kan ook voor de vrouwelijke uitreizigers worden gemaakt. Omgerekend is bijna een derde (32 procent) van de vrouwelijke uitreizigers met schuldenproblematiek geconfronteerd, tegen 17 procent van de mannen.

Tot slot, er moet rekening mee worden gehouden dat niet iedereen rood kan staan. Bij wanbetalers of probleemgevallen kunnen maatregelen zijn getroffen, zodat de rekening niet negatief kan staan. Dat gebeurt bijvoorbeeld als de volledige rekening vanuit de schuldsanering wordt overgenomen. In het laatste geval lopen de inkomsten en uitgaven niet meer over de eigen rekening, maar wordt dit tijdelijk door een gemeentelijke partner verzorgd.

\section{Zelfredzaamheid}

In de voorgaande paragrafen zijn de reguliere inkomsten van uitreizigers behandeld. Deze zijn onderverdeeld in inkomsten uit eigen arbeid, overheidssteun en studiefinanciering. In tabel 6 worden de totaalcijfers in deze categorieën voor de leesbaarheid samengevoegd.

Tabel 6 Totaalcijfers

\begin{tabular}{llllll}
\hline Maanden & I I & $\mathbf{6}$ & $\mathbf{3}$ & I & Eindtotaal \\
\hline Eigen inkomsten & 41.109 & 37.435 & 29.958 & 26.116 & 134.618 \\
Overheidssteun & 50.838 & 33.204 & 44.725 & 53.136 & 181.904 \\
Studiefinanciering & I9.294 & 24.832 & 24.878 & 25.095 & 94.098 \\
Totaalsom & III.24I & $\mathbf{9 5 . 4 7 ~ I ~}$ & $\mathbf{9 9 . 5 6 I}$ & $\mathbf{1 0 4 . 3 4 7}$ & $\mathbf{4 1 0 . 6 2 0}$ \\
\hline
\end{tabular}

Het totaal becijferde inkomen over de gemeten maanden ligt op 410.620 euro. Van dit bedrag is 33 procent vergaard door eigen arbeid (inclusief het inkomen verkregen door fraude). De overige 67 procent is door de overheid opgebracht in de vorm van overheidssteun (44 procent) en studiefinanciering (23 procent). Wat betekent dit voor de zelfredzaamheid?

Uiteindelijk blijken maar negen van de 131 personen ( 7 procent) een minimuminkomen of hoger te hebben. Maar als deze negen personen volgens het stramien van de ZRM worden gescoord, vallen er twee af omdat zij schuldenproblematiek 
hebben en/of beduidende financiële ondersteuning van de overheid ontvangen. ${ }^{8}$ Met andere woorden, slechts zeven personen (5 procent) scoren op de ZRM positief (vijf personen vallen in de categorie 'volledig zelfredzaam' en twee personen in de categorie 'voldoende').

Deze zeven personen hebben, behoudens hun positieve financiële situatie, geen duidelijke overeenkomsten. Zij schelen ruim tien jaar in leeftijd, zijn in verschillende jaren uitgereisd, behoren tot vijf verschillende etnische achtergronden, en zijn al dan niet in Nederland geboren. De een is in loondienst, terwijl de ander uitzendwerk doet, de een werkt met zijn handen, terwijl de ander een bureaufunctie heeft. Ook de transacties vertonen veel verschillen in hoogte, regelmaat en soort. De enige overeenkomst is dat zes van de zeven personen een man betreft en geen enkele persoon een bekeerling.

De overige 125 uitreizigers (95 procent) moeten als financieel 'beperkt zelfredzaam', 'niet zelfredzaam' en in een enkel geval zelfs als 'acute problematiek' worden gekwalificeerd. Deels is deze slechte score te verklaren door het relatief grote aandeel jonge mensen. Bijna de helft van alle uitreizigers ontvangt studiefinanciering, werkt nog in parttimebanen of heeft de arbeidsmarkt nog niet betreden. Kortom, zij staan nog niet op eigen benen.

Maar de situatie kan ook worden omgedraaid. Voldoende zelfredzaamheid mag worden verwacht van iedereen die 23 jaar of ouder is en al minstens een jaar geen studiefinanciering heeft ontvangen. Onder deze voorwaarden blijft een groep van 58 uitreizigers over. Van deze groep zijn slechts vijf personen financieel zelfredzaam, oftewel 9 procent.

Door het gebrek aan een goede controlegroep is het onduidelijk in hoeverre uitreizigers een uniek profiel laten zien. Het is mogelijk dat zij, voor wat betreft financiële zelfredzaamheid, niet afwijken van andere bewoners in bijvoorbeeld hetzelfde postcodegebied. Zo zijn overeenkomsten in inkomenspositie terug te vinden bij uitreizigers die studiefinanciering ontvangen en gewone studenten. Vanuit het NIBUD is namelijk berekend dat studenten $(\mathrm{N}=2.701)$ in 2015 gemiddeld 768 euro (mediaan 686 euro) aan besteedbaar inkomen ter beschikking hadden (Van der Schors e.a., 2015). Deze cijfers komen sterk overeen met uitreizigers die studiefinanciering ontvangen. Zij hadden gemiddeld zelfs 7 euro meer te besteden bij een iets lagere mediaan van 610 euro. Ook had volgens het NIBUD 76 procent van de hbo-studenten een bijbaan of betaalde stage (Van der Schors e.a., 2015). Bij uitreizigers die studiefinanciering ontvangen, ligt dit percentage op 65 procent.

Vermoedelijk hebben studerende uitreizigers wel meer financiële problemen. Volgens het NIBUD geeft 17 procent van de gewone studenten aan dat zij een financieel probleem hebben en staat 11 procent rood bij de bank (Van der Schors e.a., 2015). Bij de uitreizigers die studiefinanciering ontvangen, zijn de zaken blijkbaar zo uit de hand gelopen dat bij 22 procent een deurwaarder of schuldsanering langs is geweest. Verder staat 55 procent voortdurend rood.

8 Het eventueel ontvangen van kinderbijslag wordt niet meegenomen in de ZRM-berekening omdat dit voor iedereen met kinderen geldt. 
In tegenstelling tot jongere uitreizigers, wijken oudere uitreizigers sterker van het gemiddelde af. Een snelle vergelijking met geaggregeerde cijfers van het CBS laat zien dat 54 procent van de personen in de leeftijd van 25-44 jaar met Marokkaanse achtergrondkenmerken en 88 procent van de autochtone Nederlanders betaald werk (minimaal één uur in de week) verrichten (Huijnk \& Andriessen, 2016). Voor de Marokkaanse en Nederlandse uitreizigers is dit percentage respectievelijk 20 en 27 procent. Vooral autochtone bekeerlingen doen het financieel veel slechter dan hun vergelijkingsgroep. Volgens CBS-cijfers zouden zij een bovenmodaal inkomen moeten verdienen (Huijnk \& Andriessen, 2016). In werkelijkheid kunnen zij alleen dankzij overheidssteun de maand rondkomen. Bovendien kampen zij ook nog eens vaak met schuldenproblematiek. Opvallend genoeg ligt het percentage Marokkaanse (36 procent) en autochtone vrouwen (57 procent) met betaald werk weer relatief dicht bij de CBS-cijfers (41 en 62 procent). Hier past wel de kanttekening bij dat deze uitreizigers vaak maar gedurende een of twee meetmomenten betaalde arbeid verrichten, niet over een langere periode.

\section{Discussie}

In de literatuur wordt aangegeven dat uitreizigers in sociaaleconomisch opzicht maar matig scoren (Bakker \& De Bont, 2016; Bergema \& Van San, 2017; Weenink, 2015; Van Leyenhorst \& Andreas, 2017; Normark \& Ranstorp, 2017; Verwimp, 2016; El-Said \& Barett, 2017). Uit de analyse van bancaire gegevens kan daaraan worden toegevoegd dat uitreizigers in financieel opzicht slechts bij hoge uitzondering zelfredzaam zijn. Van de hele onderzoekspopulatie weet slechts 5 procent van de uitreizigers zijn inkomsten volledig uit eigen werk of diensten te verkrijgen, hoeft geen beroep op de overheid om financiële bijstand te doen en kampt niet met (oplopende) schulden.

Een deel van deze slechte score is te verklaren doordat bijna de helft van de uitreizigers studiefinanciering ontvangt. Het is op zich niet vreemd dat deze groep financieel weinig zelfredzaam is. Zij zijn nog relatief jong, volgen een studie, en hebben daardoor geen tijd voor fulltime werk. Sterker nog, vergeleken met gewone studenten hebben zij min of meer hetzelfde besteedbare inkomen tot hun beschikking.

Deze overeenkomst is op zich goed te verklaren. Studenten hebben allemaal recht op dezelfde hoogte van studiefinanciering, toeslagen en voorschotten en maken hier dan ook gebruik van. Verder vullen zowel gewone studenten als studerende uitreizigers hun inkomen aan met bijbaantjes (van stelselmatige uitsluiting op de arbeidsmarkt kan dus niet worden gesproken) en krijgen van familieleden soms wat toegeschoven. Hun startpositie is dus min of meer gelijk. Verder kan het moment van radicaliseren een rol hebben gespeeld. Volgens onderzoek verloopt het radicaliseringsproces bij jonge uitreizigers soms snel (Van Ham e.a., 2016; Feddes, 2017; Weggemans e.a., 2018). Er wordt gesproken over enkele maanden tot zelfs weken. Met andere woorden, als jonge uitreizigers pas kort voor hun uit- 
reis radicaliseerden, betekent dit dat er gedurende het grootste deel van de periode dat zij studiefinanciering ontvingen niks aan de hand was. ${ }^{9}$

Op één punt wijken uitreizigers die studiefinanciering ontvingen echter wel af van gewone studenten. De uitreizigers kampen namelijk over hun hele studieperiode relatief vaker met serieuze schuldenproblematiek dan gewone studenten. Ook staan zij meer rood. Het is echter onbekend of zij deze financiële problemen al vóór hun studie hadden, en zij in feite dus uit een achterstandspositie komen, of dat de financiële problemen pas tijdens de studie zijn opgelopen.

Hoe normaal de financiële positie van jongere uitreizigers ook mag lijken, op latere leeftijd wordt de aansluiting met de arbeidsmarkt grotendeels gemist. Van de groep uitreizigers die 23 jaar of ouder is, en minstens een jaar geen studiefinanciering meer heeft ontvangen, verdient slechts 9 procent het predicaat van financieel (voldoende) zelfredzaam. De rest is (sterk) afhankelijk van overheidssteun.

Een verband tussen een zwakke sociaaleconomische positie en radicalisering kan op basis van deze analyse echter niet worden aangetoond (of ontkracht). Daarvoor ontbreekt nu eenmaal het verhaal achter de cijfers. Objectief laten de bancaire gegevens zien dat een gebrek aan financiële zelfredzaamheid vrijwel altijd gepaard gaat met een succesvol beroep op de verzorgingsstaat. Op gemeentelijk en landelijk niveau wordt veel financiële ondersteuning geboden en worden eventuele schulden aangepakt. Sterker nog, vanuit overheidssteun weet een deel van de (met name vrouwelijke) uitreizigers zelfs een hoger inkomen te genereren dan een aantal werkenden die in feite in een hogere trap van zelfredzaamheid zitten. Het is echter onbekend hoe de uitreizigers hun relatieve armoede ervaren en of er in sociaaleconomisch opzicht sprake was van strain.

Een gebrek aan of verslechtering van financiële zelfredzaamheid is daarom ook geen red flag voor radicalisering of uitreizen. Nederland kent per slot van rekening slechts een paar honderd uitreizigers, terwijl er volgens cijfers van het CBS honderdduizenden personen in de bijstand zitten. ${ }^{10}$ Bovendien verschillen de financiële profielen van de uitreizigers onderling sterk. De een is volledig afhankelijk van gemeentelijke bijstand, terwijl de ander nog enig inkomen uit eigen arbeid heeft. De een krijgt een maand studiefinanciering, terwijl de ander het hele jaar van DUO geld ontvangt. De een duikt maanden voor de uitreis in de rode cijfers, terwijl de ander vlak voor vertrek nog duizenden euro's in de plus staat. De een moet betalingsregelingen met deurwaarders treffen, terwijl de ander iedere maand geld overhoudt. Als groep mogen uitreizigers dan weliswaar slecht scoren op de financiële ZRM, maar op individueel niveau laten zij een heel divers patroon zien.

Gebrekkige financiële zelfredzaamheid mag dan weliswaar geen rode vlag voor radicalisering of terrorismefinanciering zijn, in de wereld van sociale zaken is het vaak wel een indicator van multiproblematiek. Dat wil zeggen, er is dan grote kans dat er ook problemen op andere leefdomeinen optreden. Structurele proble-

9 Deze hypothese is niet nader onderzocht door het ontbreken van gegevens over het radicaliseringsproces van de onderzoeksgroep.

10 Zie www.cbs.nl/nl-nl/nieuws/2017/11/werkloosheid-neemt-verder-af. 
men op het gebied van bijvoorbeeld werk of opleiding leveren al snel een gebrekkig inkomen op, waarmee vervolgens weer huisvestingsproblemen ontstaan. Maar bij multiproblematiek moet ook aan problemen op sociaal, maatschappelijk of geestelijk vlak worden gedacht. Voor een deel is die multiproblematiek al eerder bij uitreizigers geconstateerd. Zo rapporteren Weenink (2015; 2019) en Paulussen e.a. (2017) dat uitreizigers een groep betreffen met een meer dan gemiddeld aantal psychische gezondheidsproblemen.

Wat gaat de toekomst brengen? Met de val van Raqqa eind 2017 en de verdere afbrokkeling van IS begin 2018 lijkt het probleem van uitreizigers opgelost. Vrijwel niemand verlaat Nederland nog om in Syrië aan de gewapende strijd deel te nemen. Er moet echter rekening mee worden gehouden dat daarmee het probleem van radicalisering niet is verdwenen. Ook kunnen nieuwe strijdgebieden zich in de toekomst aanbieden. Bovendien ziet de Nederlandse overheid zich inmiddels voor het probleem van de zogeheten 'terugkeerders' geplaatst, personen die ooit zijn uitgereisd en na de val van IS weer terugkomen naar Nederland.

Vanuit de financiële analyse die in dit artikel heeft plaatsgevonden, is het niet moeilijk te voorspellen dat terugkeerders de komende jaren in financieel opzicht weinig zelfredzaam zullen zijn. Nog afgezien van niet-afgemaakte opleidingen of PTSS-gerelateerde problemen heeft hun vertrek tot plaatsing op de nationale terrorismelijst of een strafblad geleid. Daarbij speelt ook nog eens de vraag in hoeverre teruggekeerde uitreizigers het radicale gedachtegoed blijven aanhangen. Als zij op de nationale terrorismelijst blijven staan (al dan niet in combinatie met het bevriezen van hun rekeningen), dan is de kans om toegang tot de Nederlandse arbeidsmarkt te verkrijgen verder weg dan ooit.

Het ligt dan ook voor de hand dat terugkeerders zich massaal tot de Nederlandse overheid zullen wenden om hun gebrek aan financiële zelfredzaamheid op te vangen. Dat is hun recht als Nederlandse staatsburger en de overheid is verplicht om in hun basisbehoeften te voorzien. Maar kan de Nederlandse overheid hier vanuit terrorismepreventie ook iets tegenover stellen? Te denken valt aan de volgende drie zaken.

Ten eerste betekent een beroep op financiële bijstand dat het de overheid een kans biedt om 'achter de voordeur' te kijken. Iemand die een beroep op de bijstand doet, moet namelijk inzicht in zijn financiële situatie geven. Dat betekent dat er diverse contactmomenten met ambtenaren van sociale zaken zijn om over de voortgang te praten. Ook huisbezoeken zijn een mogelijkheid. Door deze contacten kan actueel inzicht ontstaan in niet alleen de financiële situatie, maar ook diverse andere levensdomeinen, zoals bijvoorbeeld geestelijke gezondheid.

Ten tweede mag de overheid in het kader van de Participatiewet 2015 van uitkeringsontvangers een 'tegenprestatie naar vermogen' verlangen. Dat betekent dat gemeenten hun 'bijstandcliënten' kunnen vragen om onbetaald activiteiten te verrichten die een sociaal-maatschappelijk belang hebben. Als de vraag speelt of terugkeerders wel volledig afscheid van hun jihadistische gedachtegoed hebben genomen, dient vermeden te worden dat zij bijvoorbeeld met kwetsbare jongeren aan de slag gaan.

Ten derde kan een overweging zijn om terugkeerders voor langere periode financieel onder curatele te stellen. Als blijkt dat de overheid de voornaamste bron van 
inkomsten is voor uitreizigers en terugkeerders, is er ook wat voor te zeggen om in het kader van de bestrijding van terroristenfinanciering hier volledig toezicht op te houden.

Deze drie aanbevelingen zijn natuurlijk makkelijker gezegd dan gedaan. Het vergt veel inzicht van contactambtenaren om tekenen van (re)radicalisering bijtijds waar te nemen. Bovendien moeten zij allerlei andere doelen halen en hebben zij te maken met een grote werkdruk. Verder is het al moeilijk gebleken om gewone uitkeringsontvangers tot tegenprestaties te bewegen. Het beleid is per gemeente verschillend, maar zelfs in strenge gemeenten is het een zeer moeizaam traject. Tot slot is het onder curatele stellen van terugkeerders een dure aangelegenheid, nog afgezien van de juridische angels en voetklemmen. Wat rest is een pessimistische conclusie: Nederlandse terugkeerders zullen nog jaren financieel volledig door de Nederlandse overheid (moeten) worden opgevangen.

\section{Literatuur}

Agnew, R. (2010). A general strain theory of terrorism. Theoretical Criminology, 14(2), 131-153.

AIVD. (2017). Terugkeerders in beeld. Den Haag: Algemene Inlichtingen- en Veiligheidsdienst.

AIVD. (2018). Jaarverslag 2017. Den Haag: Algemene Inlichtingen- en Veiligheidsdienst.

AUSTRAC. (2016). Building a profile: financial characteristics associated with known foreign terrorist fighters and supporters (Methodologies Brief 01). Australian Transaction Reports and Analysis Centre.

Bakker, E. \& Bont, R. de (2016). Belgian and Dutch jihadist foreign fighters (2012-2015): characteristics, motivations, and roles in the war in Syria and Iraq. Small Wars \& Insurgencies, 27(5), 837-857.

Basra, R., Neumann, P.R. \& Brunner, C. (2016). Criminal pasts, terrorist futures: European jihadists and the new crime-terror nexus. London: ICRS.

Bergema, R. \& San, M. van (2017). Waves of the black banner: an exploratory study on the Dutch jihadist foreign fighter contingent in Syria and Iraq. Studies in Conflict \& Terrorism. Published online 14 December 2017.

Bunt, H. van de (2008). A case study on the misuse of hawala banking. International Journal of Social Economics, 35(9), 691-702.

Cottee, S. (2011). Jihadism as a subcultural response to social strain: extending Marc Sageman's 'bunch of guys' thesis. Terrorism and Political Violence, 23(5), 730-751.

Crenshaw, M. (1987). Theories of terrorism: instrumental and organizational approaches. Journal of Strategic Studies, 10(4), 13-31.

Dawson, L.L. \& Amarasingam, A. (2017). Talking to foreign fighters: insights into the motivations for hijrah to Syria and Iraq. Studies in Conflict \& Terrorism, 40(3), 191-210.

El-Said, H. \& Barett, M. (2017). Enhancing the understanding of the foreign terrorist fighters phenomenon in Syria. United Nations Office of Counter-Terrorism.

FATF. (2002). Guidance for financial institutions in detecting terrorist financing. Paris: Financial Action Task Force.

FATF. (2003). 40 recommendations. Paris: Financial Action Task Force.

FATF. (2012). The FATF recommendations: international standards on combating money laundering and the financing of terrorism \& proliferation. Paris: Financial Action Task Force. 
FATF. (2013a). International best practices on targeted financial sanctions for terrorist financing. Paris: Financial Action Task Force.

FATF. (2013b). National money laundering and terrorist financing risk assessment. Paris: Financial Action Task Force.

FATF. (2014). Risk of terrorist abuse in non-profit organisations. Paris: Financial Action Task Force.

FATF. (2015). Emerging terrorist financing risks. Paris: Financial Action Task Force.

FATF. (2016). Guidance on the criminalisation of terrorist financing (Recommendation 5). Paris: Financial Action Task Force.

Feddes, A.R. (2017). Risico-inschatting in een integraal veiligheidsbeleid. In: L. Colaert (red.). 'Deradicalisering': wetenschappelijke inzichten voor een Vlaams beleid. Brussel: Vlaams Vredesinstituut, 49-64.

Fritz, J. \& Young, J.K. (2017). Transnational volunteers: American foreign fighters combating the Islamic State. Terrorism and Political Violence. Published online 14 December 2017.

Gallagher, M. (2016). 'Criminalised' Islamic State veterans - a future major threat in organised crime development? Perspectives on Terrorism, 10(5), 51-67.

Ham, T. van, Scholten, L., Wijk, A. van, m.m.v. Holtackers, M. \& Lenders, A. (2016). Radicalisering in de gemeente Arnhem: resultaten van onderzoek onder mentoren, welzijnswerkers en jongeren. Bureau Beke.

Hegghammer, T. (2016). Revisiting the poverty-terrorism link in European jihadism. Society for Terrorism Research Annual Conference. Leiden.

Huijnk, W. \& Andriessen, I. (2016). Integratie in zicht? De integratie van migranten in Nederland op acht terreinen nader bekeken. Den Haag: Sociaal en Cultureel Planbureau.

Keatinge, T. (2015). Identifying foreign terrorist fighters: the role of public-private partnership, information sharing and financial intelligence. The Hague: The Royal United Services Institute (RUSI)/International Centre for Counter-Terrorism (ICCT).

Kleemans, E.R., Brienen, M.E.I., Bunt, H.G. van de, m.m.v. Kouwenberg, R.F., Paulides, G. \& Barendsen, J. (2002). Georganiseerde criminaliteit in Nederland: tweede rapportage op basis van de WODC-monitor. Den Haag: WODC.

Klerks, P.P.H.M. (2000). Groot in de hasj: theorie en praktijk van de georganiseerde criminaliteit. Alphen aan den Rijn: Samsom.

Kruisbergen, E.W. (2017). Combatting organized crime: a study on undercover policing and the follow-the-money strategy. Amsterdam: Vrije Universiteit.

LaFree, G., \& Ackerman, G. (2009). The empirical study of terrorism: Social and legal research. Annual Review of Law and Social Science, 5, 347-374.

Lauriks, S., Buster, M., Wit, M. de, Weerd, S. van de, Kamann, T., Boom, W. van den e.a. (2017). Handleiding Zelfredzaamheid-Matrix 2017. Amsterdam/Rotterdam: GGD Amsterdam/GGD Rotterdam.

Leyenhorst, M. van \& Andreas, A. (2017). Dutch suspects of terrorist activity: a study of their biographical backgrounds based on primary sources. Journal for Deradicalization (12), 309-344.

Ljujic, V., Prooijen, J.W. van \& Weerman, F. (2017). Beyond the crime-terror nexus: socioeconomic status, violent crimes and terrorism. Journal of Criminological Research, Policy and Practice, 3(3), 158-172.

Miller, C. \& Chauhan, L.S. (2017). Radicaal gedachtegoed en gewelddadig gedrag. In: L. Coleart (red.). 'Deradicalisering': wetenschappelijke inzichten voor een Vlaams beleid. Brussel: Vlaams Vredesinstituut, 25-48.

Monahan, J. (2012). The individual risk assessment of terrorism. Psychology, Public Policy, and Law, 18(2), 167-205. 
NCTV. (2014). Actieprogramma integrale aanpak jihadisme: overzicht maatregelen en sancties. Ministerie van Veiligheid en Justitie/Nationaal Coördinator Terrorismebestrijding en Veiligheid/Ministerie van Sociale Zaken en Werkgelegenheid.

NCTV. (2018). Dreigingsbeeld Terrorisme Nederland 47. Den Haag: Nationaal Coördinator Terrorismebestrijding en Veiligheid.

NCTV \& AIVD. (2017). Minderjarigen bij ISIS: een publicatie van de NCTV en de AIVD. Den Haag: Nationaal Coordinator Terrorismebestrijding en Veiligheid \& Algemene Inlichtingen- en Veiligheidsdienst.

Normark, M. \& Ranstorp, M. (2017). Financial activities linked to persons from Sweden and Denmark who joined terrorist groups in Syria and Iraq during the period 2013-2016. CATS - Center for Asymmetric Threat Studies.

Oftedal, E. (2015). The financing of jihadi terrorist cells in Europe. Norway: Forsvarets forskninginstitutt (Norwegian Defence Research Establishment - FFI).

Paulussen, C., Nijman, J. \& Lismont, K. (2017). Mental health and the foreign fighter phenomenon: a case study from the Netherlands. The Hague: International Centre for CounterTerrorism (ICCT).

Russel, C.A. \& Miller, B.H. (1977). Profile of a terrorist. Terrorism, 1(1), 17-34.

San, M. van (2017). Belgian and Dutch young men and women who joined ISIS: ethnographic research among the families they left behind. Studies in Conflict \& Terrorism, 41(1), 39-58.

Schils, N. \& Pauwels, L. (2014). Explaining violent extremism for subgroups by gender and immigrant background, using SAT as a framework. Journal of Strategic Security, 7(3), 27-47.

Schors, A. van der, Schonewille, G. \& Werf, M. van der (2015). Studentenonderzoek 2015: achtergrondstudie bij Handreiking Student \& Financiën. Nationaal Instituut voor Budgetvoorlichting (NIBUD).

Schors, A. van der, Werf, M. van der \& Boer, M. (2016). Kans op financiële problemen. Nationaal Instituut voor Budgetvoorlichting (NIBUD).

Schuurman, B. (2018). Becoming a European homegrown jihadist. A multilevel analysis of involvement in the Dutch Hofstadgroup, 2002-2005. Amsterdam: Amsterdam University Press.

Spapens, T. (2006). Interactie tussen criminaliteit en opsporing: de gevolgen van opsporingsactiviteiten voor de organisatie en afscherming an xtc-productie en -handel in Nederland. Antwerpen: Intersentia.

Verwimp, P. (2016). Foreign fighters in Syria and Iraq and the socio-economic environment they faced at home: a comparison of European countries. Perspectives on Terrorism, 10(6), 68-81.

Weenink, A.W. (2015). Behavioral problems and disorders among radicals in police files. Perspectives on Terrorism, 9(2), 17-33.

Weenink, A.W. (2019). De Syriëgangers. Korps Nationale Politie, Landelijke Eenheid, Dienst Landelijke Informatieorganisatie, Analyse \& Onderzoek - Team CTER.

Weggemans, D., Zwan, M. van der \& Liem, M. (2018). Familie van uitreizigers: een onderzoek naar de rol van familieleden bij processen van uitreizen naar en terugkeren uit buitenlandse jihadistische strijdgroepen. Den Haag: WODC.

Yusoufzai, K. \& Emmerling, F. (2017). Explaining violent radicalization in Western Muslims: a four factor model. Journal of Terrorism Research, 8(1), 68-80. 